\title{
In Vitro Corrosion Behavior of Biodegradable Iron Foams with Polymeric Coating
}

\author{
Radka Gorejová ${ }^{1}$, Renáta Oriňaková ${ }^{1, *}{ }^{\mathbb{O}}$, Zuzana Orságová Králová ${ }^{1}$, Matej Baláž ${ }^{2} \mathbb{1}$, \\ Miriam Kupková ${ }^{3}$, Monika Hrubovčáková ${ }^{3}{ }^{\circledR}$, Lucia Haverová ${ }^{1}$, Miroslav Džupon ${ }^{3}$, \\ Andrej Oriňak ${ }^{1}$, František Kal'avský ${ }^{1}$ and Karol Koval' $^{3}$ \\ 1 Department of Physical Chemistry, Faculty of Science, Pavol Jozef Šafárik University in Košice, \\ Moyzesova 11, 04154 Košice, Slovakia; radka.gorejova@student.upjs.sk (R.G.); \\ zuzana.orsagova.kralova@upjs.sk (Z.O.K.); markusovabuckova@gmail.com (L.H.); \\ andrej.orinak@upjs.sk (A.O.); frantisek.kalavsky@upjs.sk (F.K.) \\ 2 Institute of Geotechnics, Slovak Academy of Sciences, Watsonova 45, 04001 Košice, Slovakia; \\ balazm@saske.sk \\ 3 Institute of Materials Research, Slovak Academy of Sciences, Watsonova 47, 04001 Košice, Slovakia; \\ mkupkova@saske.sk (M.K.); mhrubovcakova@saske.sk (M.H.); mdzupon@saske.sk (M.D.); \\ kkoval@saske.sk (K.K.) \\ * Correspondence: renata.orinakova@upjs.sk; Tel.: +421-55-234-2324
}

Received: 17 December 2019; Accepted: 28 December 2019; Published: 2 January 2020

check for updates

\begin{abstract}
Research in the field of biodegradable metallic scaffolds has advanced during the last decades. Resorbable implants based on iron have become an attractive alternative to the temporary devices made of inert metals. Overcoming an insufficient corrosion rate of pure iron, though, still remains a problem. In our work, we have prepared iron foams and coated them with three different concentrations of polyethyleneimine (PEI) to increase their corrosion rates. Scanning electron microscopy (SEM) coupled with energy dispersive X-ray analysis (EDX), Fourier-transform infrared spectroscopy (FT-IR), and Raman spectroscopy were used for characterization of the polymer coating. The corrosion behavior of the powder-metallurgically prepared samples was evaluated electrochemically using an anodic polarization method. A 12 weeks long in vitro degradation study in Hanks' solution at $37^{\circ} \mathrm{C}$ was also performed. Surface morphology, corrosion behavior, and degradation rates of the open-cell foams were studied and discussed. The use of PEI coating led to an increase in the corrosion rates of the cellular material. The sample with the highest concentration of PEI film showed the most rapid corrosion in the environment of simulated body fluids.
\end{abstract}

Keywords: iron foam; polyethyleneimine (PEI); biodegradation; powder metallurgy; coating

\section{Introduction}

In recent years, the development of biodegradable orthopedical scaffolds has advanced significantly [1-7]. Resorbable materials are intended to serve as temporary support for damaged tissue. Compared to the standard medical devices typically made of stainless steel, cobalt-chromium, or titanium alloys [8], this new group of materials possess a particular advantage in the form of in vivo self-adsorbing capacity. Corrosion is therefore no longer seen as a problem, and appropriate biodegradable devices can be made by targeted designing and influencing of their degradation rates.

Iron-based biodegradable materials (Fe-BM) are considered a suitable alternative to permanent metallic implants [9-15]. They showed satisfactory cytocompatibility in previous studies and their mechanical properties could match those of natural bone $[9,16,17]$. Hydrogen evolution, too rapid degradation, or suppressed antibacterial performance, problems associated with the other most-studied 
biodegradable metal-magnesium, are not present in the case of iron [18,19]. However, the disadvantage of very slow degradation in physiological $\mathrm{pH}$ has to be overcome. There have been several reports studying the corrosion behavior of Fe-BM using different approaches to solve this issue. One of the most used methods to fasten the degradation is alloying with another element(s). Manganese, platinum, sulfur, carbon, palladium, etc. were tested in different ratios to the iron [10,15,20-22]. Even though these additions managed to accelerate iron degradation, mechanical properties or overall biocompatibility are often impaired. Degradation of BM depends on various factors and it is known that besides the composition of the specimen, the preparation method and its geometrical form plays also an important role [23]. The porous structure is beneficial for healthy vascularization and tissue ingrowth and is typically used in the field of orthopedic implants [24-26].

Another way to enhance corrosion, but also improve the biological performance of prepared material, is the usage of different coatings. Three groups of coating materials are usually used. The first group consists of inorganic ceramic coatings where hydroxyapatite (HAp) and other calcium phosphates (tricalcium phosphates (TCP), biphasic calcium phosphates (BCP)) have a leading position due to their similarity to the inorganic component of natural bone, osteoconductivity, and osseointegration properties $[23,27,28]$. Representatives of the second group are the metal-ceramic composites (calcium silicate-iron e.g., [29].)

Polymers are the third group of the coating materials for bioabsorbable metals. Poly-lactic-acid (PLA), poly-lactic-co-glycolic acid (PLGA), or polyethyleneglycol (PEG) are used to the highest extent $[25,30,31]$. It is known that the passivation layer of corrosion products can be formed on the surface of the specimen which retards further corrosion. Yusop et al. [31] found that $\mathrm{pH}$ in the proximity to the metal surface can be lowered by the polymer degradation and therefore the solubility of this passive layer is enhanced as long as the solubility of these corrosion products (mostly calcium or magnesium phosphates, iron hydroxides, etc.) is higher in the lower $\mathrm{pH}$. This can lead to higher corrosion rates of the studied implants. Polymeric coating, though, can not only enhance the corrosion rate but also improve the biological performance of the scaffold. When PEG was used, the positive effect on the material biocompatibility was observed [32].

Polyethyleneimine (PEI) is an organic polymer soluble in water and ethanol with a high density of amino groups which can be protonated $[33,34]$. This polycation exists in linear or branched form and its properties depend on molecular weight and structure [35]. PEI has been studied for several decades [36] and found its place in various biological applications. It can be utilized as a drug carrier [35], in tumor imaging [37], or in gene transduction into mesenchymal stem cells (MSCs) [38]. The cytotoxic effect of the PEI relies upon the size, structure, and its ratio. Xia et al. [35] found, that by a careful selection of PEI size, it is possible to achieve minimal or no cytotoxicity. Yao et al. [38] confirmed that not only the size, but also the concentration of the coated layer, has an influence on the resulting cytotoxicity, which can be adjusted by careful choosing. Moreover, the polycationic character of PEI due to the amino groups' protonation can interact with negatively charged bacteria [34]. Several studies confirmed improvement of the biocompatibility of PEI-coated materials [36,38]. In addition to this, the PEI structure provides possibilities to modify it with various polymers, create layers (e.g., PEG, chitosan), and furthermore, to load it with drugs that could possibly take a place in the bone healing process [34,38-40].

In our work, we have prepared foam-like scaffolds from the carbonyl iron powder (CIP) via the powder metallurgy process. Inspired by our previous work on Fe-PEG [30] material, we used polyethyleneimine as a coating material, which was deposited on the surface of the Fe sample using a cost-effective dip-coating method. The morphology of the sample's surface was studied prior to coating and after depositing the PEI layer in three different concentrations. To determine the corrosion rate in a physiological environment, electrochemical potentiodynamic tests and in vitro immersion tests were carried out using Hanks' solution to mimic body fluids. The composition and appearance of the corrosion products created after 4,8 , and 12 weeks of immersion were examined and the influence of the polymeric layer on corrosion of the iron scaffold was discussed. 


\section{Materials and Methods}

\subsection{Material Preparation}

Porous iron samples were prepared from carbonyl iron powder (CIP) by BASF (type CC d50, 3.8-5.3 $\mu \mathrm{m} ; 99.5 \% \mathrm{Fe}, 0.05 \% \mathrm{C}, 0.01 \% \mathrm{~N}, 0.18 \% \mathrm{O}$ ) by the impregnation of the polyurethane (PUR) foam (Filtren, TM 25133). The impregnating suspension consisted of $7 \mathrm{~g}$ of CIP iron powder, $6 \mathrm{~mL}$ of distilled water, and $0.2 \mathrm{~g}$ of gelatine (Sigma-Aldrich) dissolved at $60{ }^{\circ} \mathrm{C}$ for better adhesion of iron slurry to the PUR foam. Cylindrical ( $5 \mathrm{~mm}, \mathrm{~h} 15 \mathrm{~mm}$ ) foams were impregnated for $24 \mathrm{~h}$ and thermally treated in a tube furnace (ANETA 1) at $450{ }^{\circ} \mathrm{C}$ for $1 \mathrm{~h}$ in $\mathrm{N}_{2}$ atmosphere (for PUR matrix elimination) and sintered at $1120{ }^{\circ} \mathrm{C}$ for $1 \mathrm{~h}$ in a reduction atmosphere $\left(10 \% \mathrm{H}_{2}, 90 \% \mathrm{~N}_{2}\right)$ to obtain the final structure. CIP pellets (Ø $10 \mathrm{~mm}$, h $2 \mathrm{~mm}$ ) used for Raman spectroscopy experiments were prepared by cold pressing iron powder at $600 \mathrm{MPa}$, subsequent sintering at $1120{ }^{\circ} \mathrm{C}$ for $1 \mathrm{~h}$ in a reduction atmosphere $\left(10 \% \mathrm{H}_{2}, 90 \% \mathrm{~N}_{2}\right)$, and coated as described below.

\subsection{PEI Coating Preparation}

Polyethyleneimine (Sigma-Aldrich; $50 \%(w / v)$ in $\mathrm{H}_{2} \mathrm{O}$ ) film was achieved by a dip-coating process. Samples were ultrasonically cleaned in acetone and ethanol, in each for $10 \mathrm{~min}$, and dipped into three different PEI solutions (5, 10, and 15 wt \% corresponding to PEI1, PEI2, and PEI3, respectively) for $90 \mathrm{~min}$ and then dried at $37^{\circ} \mathrm{C}$ for $12 \mathrm{~h}$.

\subsection{Microstructure and Surface Characterization}

The microstructure of porous iron foams before and after 4, 8, and 12 weeks of corrosion was observed using an optical microscope (Olympus GX71, OLYMPUS Europa Holding GmbH, Hamburg, Germany). Samples were molded into the methyl-methacrylate resin (Dentacryl), hardened, and grinded.

Scanning electron microscopy (SEM, Jeol Ltd., Tokyo, Japan) and energy dispersive X-ray analysis (EDX) (JOEL JSM-7001F with INCA EDX analyzer, Oxford Instruments, Abingdon, Oxfordshire, UK) were used for surface morphology characterization.

The specific surface area $\left(\mathrm{S}_{\mathrm{BET}}\right)$ was determined by the low-temperature nitrogen adsorption method using a NOVA 1200e Surface Area and Pore Size Analyzer (Quantachrome Instruments, Hartley Wintney, UK). The values were calculated using Brunauer-Emmett-Teller (BET) theory.

The Fourier-transform infrared spectroscopy (FT-IR) spectra were recorded on the Tensor 29 infrared spectrometer (Bruker, Karlsruhe, Germany) using the attenuated total reflection (ATR) method.

The Raman spectra were recorded using a Renishaw inVia spectrophotometer (Renishaw UK Sales Ltd., Wotton-under-Edge, UK). All spectra were recorded through 4x-objective using a $532 \mathrm{~nm}$ laser from 100 to $4000 \mathrm{~cm}^{-1}$ at a $50 \%$ laser power. The samples were exposed to the laser for $10 \mathrm{~s}$ with 3 accumulations.

\subsection{Electrochemical Corrosion Testing}

The electrochemical measurements were conducted in Hanks' solution $(8 \mathrm{NaCl}, 0.4 \mathrm{KCl}$, $0.14 \mathrm{CaCl}_{2}, 0.06 \mathrm{MgSO}_{4} .7 \mathrm{H}_{2} \mathrm{O}, 0.06 \mathrm{NaH}_{2} \mathrm{PO}_{4} .2 \mathrm{H}_{2} \mathrm{O}, 0.35 \mathrm{NaHCO}_{3}, 1.00$ glucose, $0.60 \mathrm{KH}_{2} \mathrm{PO}_{4}$, and $0.10 \mathrm{MgCl}_{2} \cdot 6 \mathrm{H}_{2} \mathrm{O}$ in $\mathrm{g} / \mathrm{L}$ ) with $\mathrm{pH} 7.4 \pm 0.2$ at $37 \pm 1{ }^{\circ} \mathrm{C}$ using a potentiostat (Autolab PGSTAT $302 \mathrm{~N})$. A three-electrode system with $\mathrm{Ag} / \mathrm{AgCl} / \mathrm{KCl}(3 \mathrm{~mol} / \mathrm{L})$ as a reference electrode, platinum counter electrode, and iron sample as the working electrode were used. The potentiodynamic polarization tests were carried out from -1000 to $-300 \mathrm{mV}$ (vs. $\mathrm{Ag} / \mathrm{AgCl} / \mathrm{KCl}(3 \mathrm{~mol} / \mathrm{L})$ ) at a scanning rate of $0.1 \mathrm{mV} / \mathrm{s}$. The corrosion rate was determined using the Tafel extrapolation method and calculated from Equation (1), where $C R$ is corrosion rate, $j_{\text {corr }}$ is corrosion current density $\left(\mu \mathrm{A} / \mathrm{cm}^{2}\right), K$ is a constant $\left(3.27 \times 10^{-3}\right)$ 
determining output units of $C R, E W$ is equivalent weight ( $27.92 \mathrm{~g} / \mathrm{eq}$ for $\mathrm{Fe})$, and $d$ is the iron foam density $\left(0.024 \mathrm{~g} / \mathrm{cm}^{3}[41]\right)$.

$$
C R=\frac{j_{c o r r} K E W}{d}
$$

\subsection{Immersion Test}

Before the static immersion test, all uncoated samples were ultrasonically cleaned in acetone and ethanol for $10 \mathrm{~min}$, air-dried, and weighed. Static immersion tests were conducted for 12 weeks at $37^{\circ} \mathrm{C}$. Corrosion rates were calculated from Equation (2), where $m_{f}$ is sample weight after degradation $(\mathrm{g}), m_{i}$ is sample weight at the beginning of the experiment $(\mathrm{g}), K$ is the constant $\left(8.76 \times 10^{4}\right), A$ is the sample area $\left(\mathrm{cm}^{2}\right), t$ is the exposure time $(\mathrm{h})$, and $d$ is the material density $\left(\mathrm{g} / \mathrm{cm}^{3}\right)$. Samples were immersed in $120 \mathrm{~mL}$ of Hanks' solution and the uniform access of the corrosion medium to the whole sample surface was ensured.

$$
C R=\frac{\left(m_{i}-m_{f}\right) 8.76 \times 10^{-4}}{A t d}
$$

$\mathrm{pH}$ of Hanks' solution was measured, and total iron content was determined using atomic absorption spectroscopy on AAnalyst 100 after 4, 8, and 12 weeks of corrosion.

\section{Results and Discussion}

\subsection{Material Characterization}

\subsubsection{Morphology of the Sintered Iron Foam}

Cellular iron-based samples intended to serve as a potential orthopedic implant were prepared via the powder-metallurgical route. A little shrinkage of the specimens occurred after sintering when compared to the size of green compacts. Open porosity was well-preserved, which indicates a good material capacity for further tissue growth through the implant. Pores in the micrometer range (600 to $2000 \mu \mathrm{m}$ ) were present alongside smaller pores in the range of 0.5 to $6 \mu \mathrm{m}$, as shown in Figure 1 . The surface of the sintered foams was humpy, as shown in Figure 1b, which can be attributed to the spherical character of the iron powder particles serving as raw material. Metallographic cross-sections of the pure iron foams, as shown in Figure $1 \mathrm{c}, \mathrm{d}$, confirmed these observations and showed a highly micro-porous structure.

Thinning of the cell walls occurred at their centers and the widest wall size was observed at the cell joints. Evaporation of gases after PUR foam elimination led to the creation of a third type of porosity, which was localized randomly, only in some regions of the samples, as shown in Figure 1c. This uncertain porosity should impair the mechanical properties of the specimen and should be considered and eliminated in the future fabrication process.

\subsubsection{Characterization of the Polymer Coating}

Sintered iron foams were ultrasonically cleaned and dip-coated with three different concentrations of PEI. The thin polymeric coating was observed after solvent evaporation. Ethanol (96 vol \%) was selected as a solvent to achieve fast evaporation and to minimize the risk of material corrosion during the manufacturing processes. The presence of the polymeric layer was confirmed by the EDX method, where nitrogen, carbon, and oxygen were spotted for the coated samples while only iron was detected for the uncoated specimen, as shown in Figure 2. The average (from 10 measurements) weight of the resultant coating for different PEI concentrations and corresponding weight percentage is summarized in Table 1. While the PEI1 coating forms almost $2.0 \mathrm{wt} \%$ of the sample, it is $5.0 \mathrm{wt} \%$ for the PEI2 and $6.6 \mathrm{wt} \%$ for the PEI3 sample. The small difference between the weight of the PEI 2 and PEI 3 coating should be attributed to the higher saturation on the sample surface and depletion of the free space 
available for deposition. Similar space occupation by the polymeric layer for PEI2 and PEI3 can be seen in Figure 3i,l, while the uncoated areas are present when the sample is coated with only PEI1 (5 wt \% of PEI) solution.
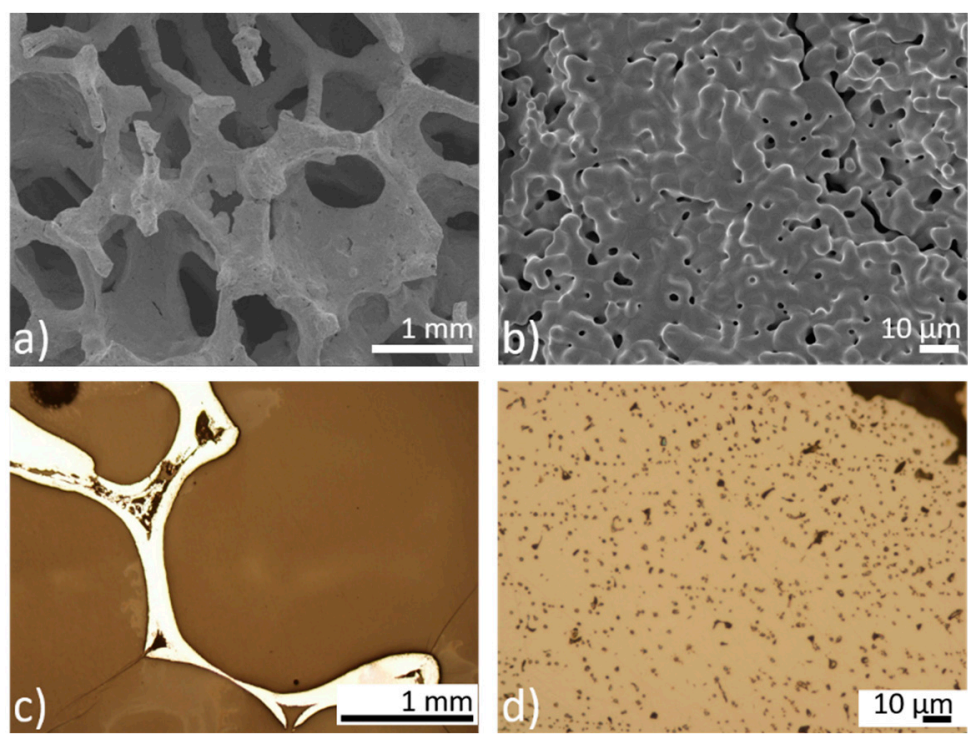

Figure 1. (a,b) The scanning electron microscopy (SEM) micrographs of the sintered iron scaffold; (c,d) metallographic cross-sections of the sintered iron scaffold. Comparison of the different porosities present in the material.
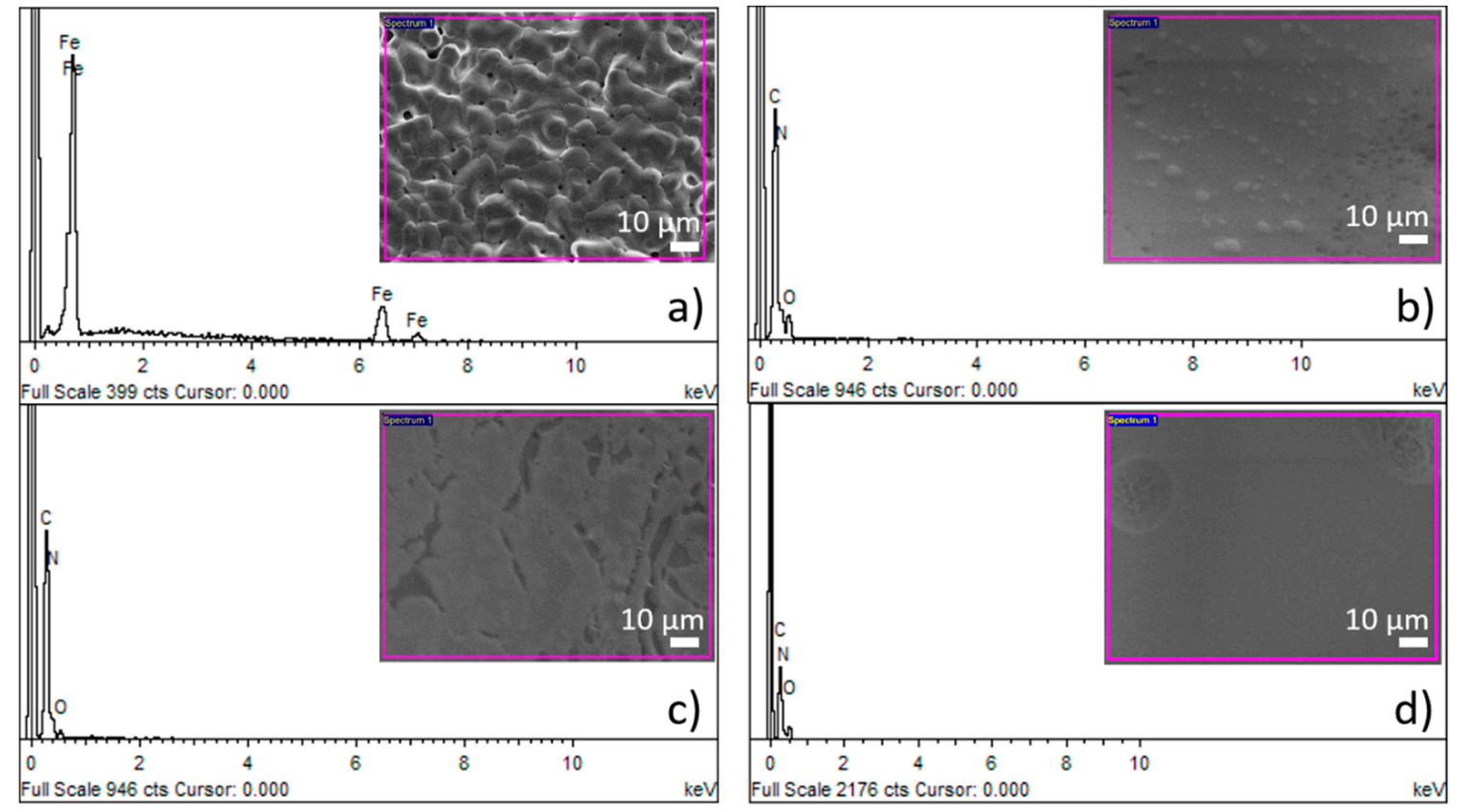

Figure 2. Chemical composition of the surface of (a) pure Fe; (b) Fe-PEI1; (c) Fe-PEI2; and (d) Fe-PEI3 samples studied by the energy dispersive X-ray analysis (EDX) method.

Table 1. Average weight (mg) and content (wt \%) of polyethyleneimine (PEI) coating deposited on the surface of the iron foams.

\begin{tabular}{cccc}
\hline & Fe-PEI1 & Fe-PEI2 & Fe-PEI3 \\
\hline Average PEI weight $(\mathrm{mg})$ & 15.9 & 41.4 & 53.6 \\
Average PEI content $(\mathrm{wt} \%)$ & 1.9 & 5.0 & 6.6 \\
\hline
\end{tabular}



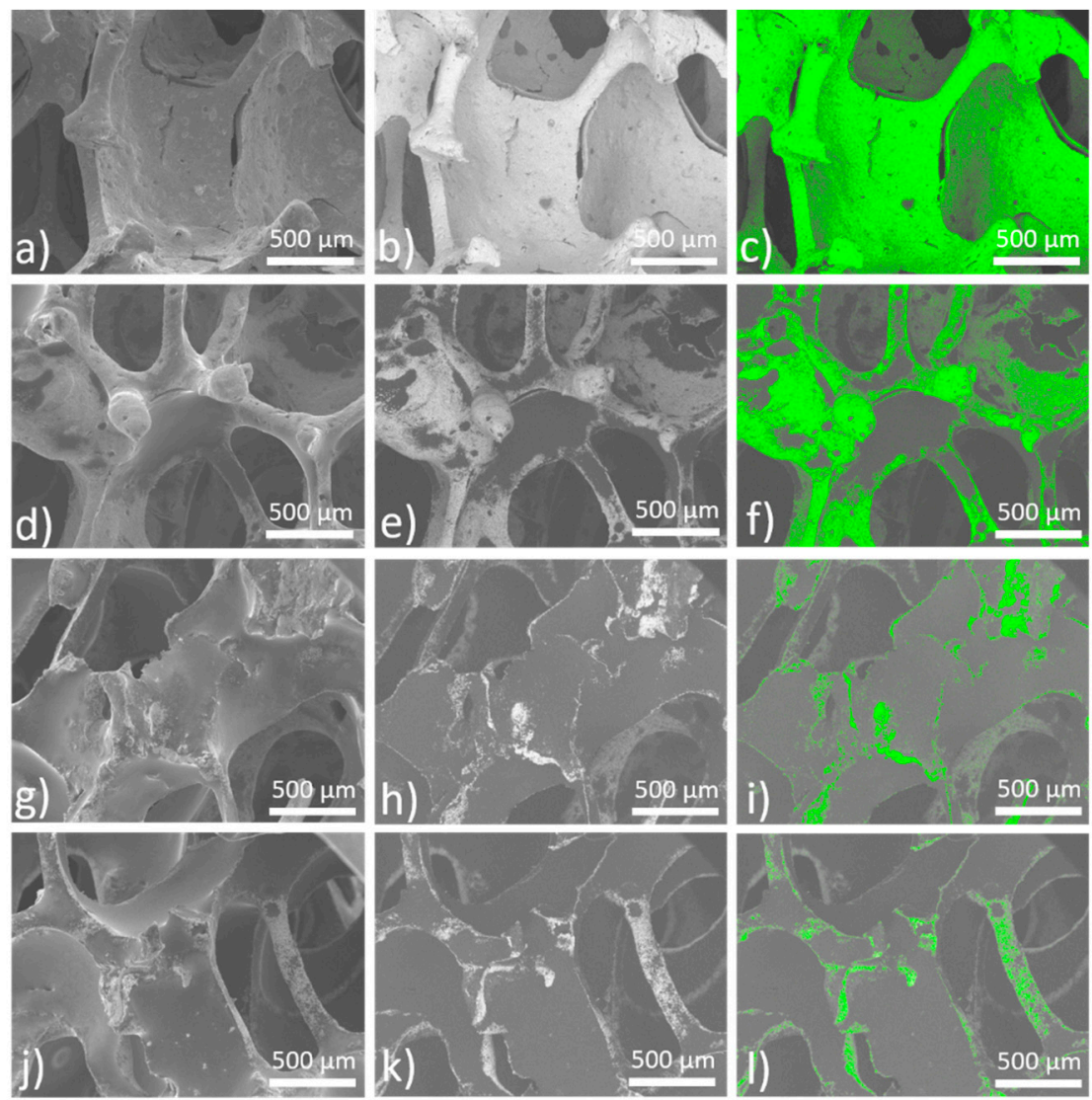

Figure 3. SEM micrographs of the prepared $(\mathbf{a}-\mathbf{c})$ Fe; $(\mathbf{d}-\mathbf{f})$ Fe-PEI1; (g-i) Fe-PEI2; and (j-1) Fe-PEI3 materials. Iron matrix is highlighted in green for better contrast in $(\mathbf{c}, \mathbf{f}, \mathbf{i}, \mathbf{l})$.

Polymer distribution on the surface of iron matrix for the samples with different content of the polymer is depicted in Figure 3. SEM micrographs were taken in two different scanning modes (Secondary Electron Imaging (SEI) and Composition (COMPO)) for better evaluation of the polymer surface distribution. Difference between the heavy elements (e.g., Fe) and the light elements (e.g., C, O, N) is displayed as a color difference-the heavier is the element, the lighter is the color in which it is displayed. In Figure $3 c, f, i, 1$, pure iron is graphically highlighted in green for better contrast. It can be seen that the coating on the Fe-PEI1 sample does not cover the entire surface and the polymer is mostly localized in the cell valleys, while the coverage of the wall edges is incomplete, as shown in Figure 3c. With the higher polymer concentration, coverage of the material increases, however, the edges of the walls still remain uncoated. Surface smoothing with increasing coverage of the iron substrate by the polymer layer led to the creation of the homogeneous surface. Polymer addition led to the micropores filling with coating material, as shown in Figure 4. The specific surface area $\left(\mathrm{S}_{\mathrm{BET}}\right)$ significantly decreased with the increasing polymer concentration, as shown in Table 2. This finding is similar to the results observed for the Fe-PEG material [30], where surface area increased after the first addition of polymer but decreased continuously with increasing polymer concentration. It can be seen that coating with PEI does not lead to the creation of islands of polymer and its use resulted in the smoothing of the coated surface. In the case of very porous substances with large specific surface areas, like activated carbon or fibrous silica, the addition of PEI also decreased the $\mathrm{S}_{\mathrm{BET}}$ value [42,43]. The surface area plays an important role in the evaluation of the corrosion measurements and therefore should not be neglected in further analysis. 

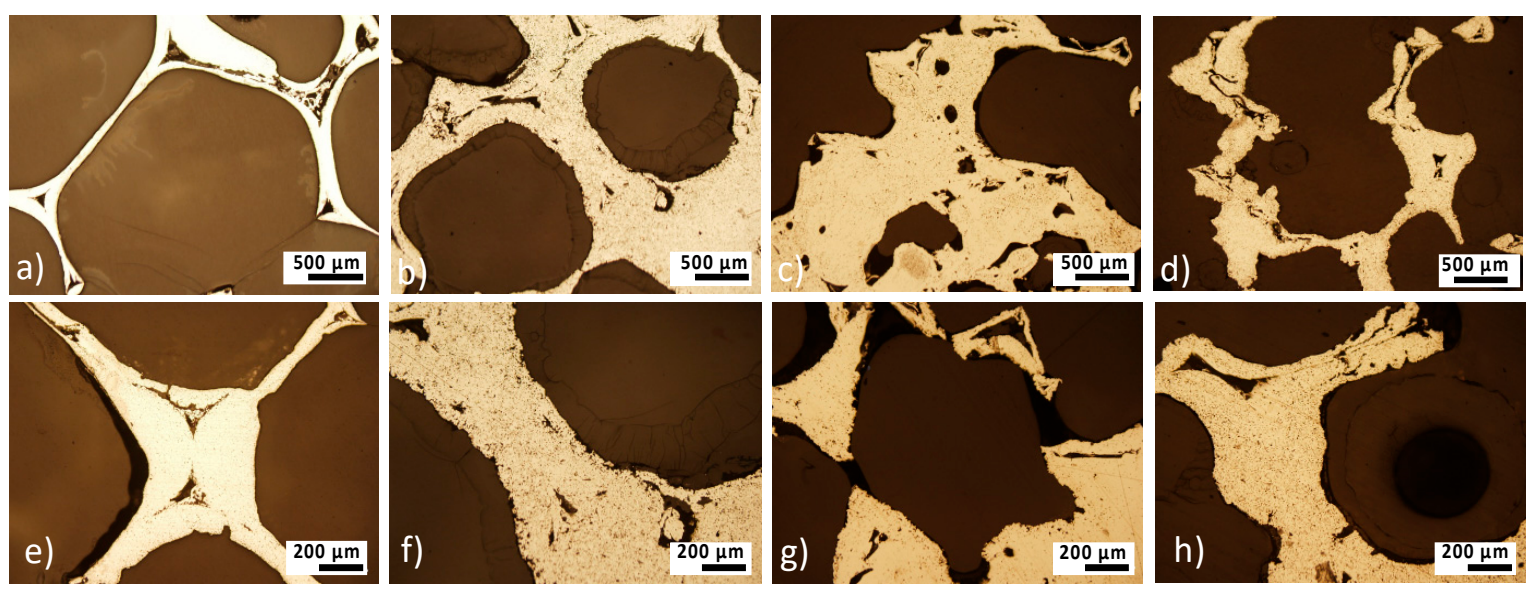

Figure 4. Metallographic cross-sections of the (a,e) Fe; (b,f) Fe-PEI1; (c,g) Fe-PEI2; and (d,h) Fe-PEI3 before corrosion.

Table 2. Specific surface area $\left(\mathrm{S}_{\mathrm{BET}}\right)$ of the PEI coated (Fe-PEI) and the uncoated (pure Fe) foams.

\begin{tabular}{cccc}
\hline \multicolumn{4}{c}{$\mathrm{S}_{\text {BET }}\left(\mathrm{g} \mathrm{m}^{-2}\right)$} \\
\hline Fe & Fe-PEI1 & Fe-PEI2 & Fe-PEI3 \\
1.19 & 0.92 & 0.61 & 0.04 \\
\hline
\end{tabular}

The polymeric layer was confirmed and analyzed by different methods. FT-IR and Raman spectra were recorded before the corrosion of material to study the PEI layer and its interaction with the Fe matrix, as shown in Figure 5.
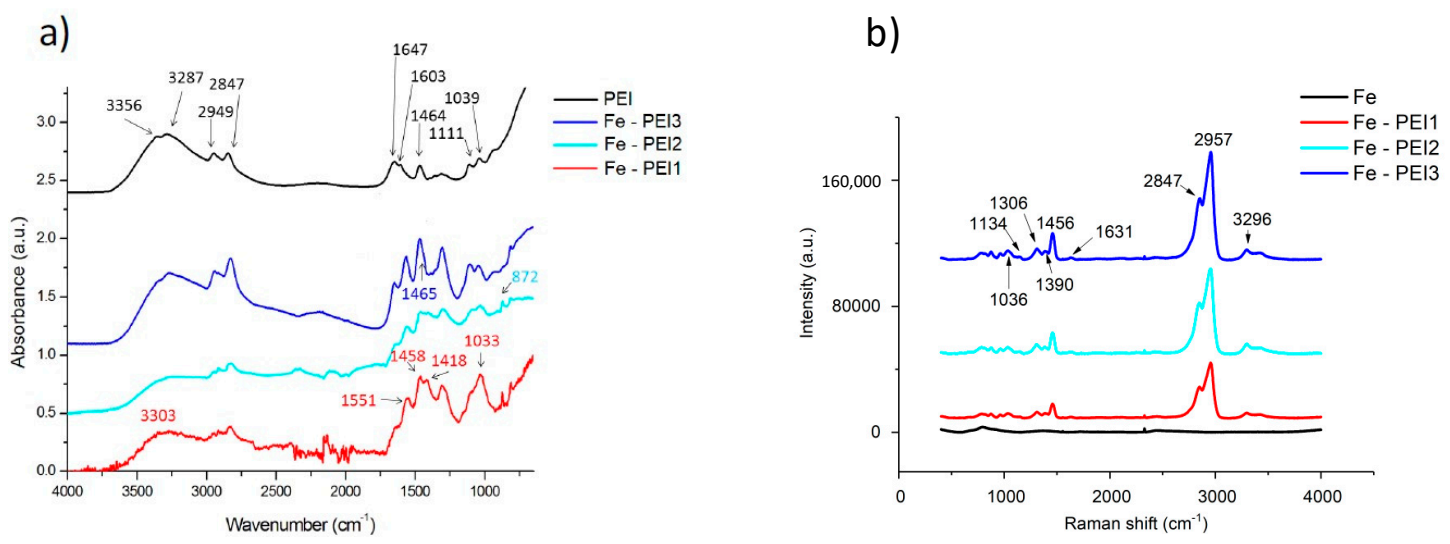

Figure 5. The spectra of pure iron and PEI coated scaffolds recorded using (a) FT-IR and (b) Raman spectroscopy.

The vibrations of the functional groups of PEI can be found at the following wavenumber in the spectrum of pure PEI: the stretching vibrations of the $-\mathrm{NH}_{2}$ group at 3356 and $3287 \mathrm{~cm}^{-1}$, the asymmetric and symmetric stretching vibrations of $-\mathrm{CH}_{2}$ group at 2949 and $2847 \mathrm{~cm}^{-1}$, the bending vibration of the $-\mathrm{NH}_{2}$ group at $1603 \mathrm{~cm}^{-1}$, the in-plane bending vibration of the $-\mathrm{CH}_{2}$ group at $1464 \mathrm{~cm}^{-1}$, and the stretching vibration of the $\mathrm{C}-\mathrm{N}$ group at $1111 \mathrm{~cm}^{-1}$. These positions are in accordance with recent literature [44-46]. After the interaction of PEI with Fe, the spectrum has significantly changed, as the majority of the peaks were shifted and also their intensity changed, as shown in Figure 5a. Moreover, there are differences among the Fe-PEI samples. Basically, for the samples with the low PEI content, the intensity of the peaks corresponding to the vibrations of the $-\mathrm{NH}_{2}$ group has significantly decreased in the case of these samples, meaning that this group can be mainly responsible for the interaction 
with iron. Furthermore, the new peak located at $872 \mathrm{~cm}^{-1}$ was evidenced. It is possible that the most effective interaction between Fe and the polymer is achieved when a smaller amount of PEI is used.

Figure $5 b$ depicts the Raman spectrum of the PEI in different concentrations deposited on the surface of the CIP pellets. The bands at $1456 \mathrm{~cm}^{-1}$ and bands at 1306,1134 , and $1036 \mathrm{~cm}^{-1}$ correspond to the methylene $-\mathrm{CH}_{2}$ group (wagging and twisting motions) and could be also found in the spectra of the pure polyethylene and ethylenediamine [47]. The 1456 and $1306 \mathrm{~cm}^{-1}$ bands are also present in the spectrum of the pure $50 \mathrm{wt} \%$ PEI solution, which was observed in [47]. Bands at the $1631 \mathrm{~cm}^{-1}$ correspond to the amino group $\left(-\mathrm{NH}_{2}\right)$. Intensive bands corresponding to the $\mathrm{C}-\mathrm{H}$ bond are present at 2700 to $3100 \mathrm{~cm}^{-1}$, which is in accordance with the literature [48]. Different conformational changes could appear during the polymer adsorption to the surface. Symmetric and asymmetric valence vibrations are slightly shifted in the spectrum due to the amino groups in the PEI structure. In the pure $50 \mathrm{wt} \%$ PEI spectrum are these bands at 2956 and $2866 \mathrm{~cm}^{-1}$, but due to the adsorption processes to the metallic surface, these could be shifted (from $2866 \mathrm{~cm}^{-1}$ to $2847 \mathrm{~cm}^{-1}$ in this case). Chaufer [49] studied PEI adsorption onto $\mathrm{Zr}$ and assumed that the Lewis acid-base bonding occurs between the amino groups and the metal, which was also reported in the case of silver [47]. However, the phenomenon was observed when the $-\mathrm{NH}_{2}$ group band $\left(1600 \mathrm{~cm}^{-1}\right)$ was shifted to the lower values. We have observed shift to the higher values $\left(1631 \mathrm{~cm}^{-1}\right)$, therefore this type of interaction probably could not be applied to our system. Despite this fact, the analysis of the FT-IR spectra of coated foams discussed earlier in this work confirmed the interaction between the amino group and the metal surface.

\subsection{Degradation Study}

\subsubsection{Potentiodynamic Polarization Tests}

For the evaluation of the degradation rates of coated and uncoated samples, a potentiodynamic polarization test was performed. Corrosion current density $\left(j_{\text {corr }}\right)$, corrosion potential $\left(E_{\text {corr }}\right)$, and the polarization resistance are summarized in Table 3. Potentiodynamic curves obtained during the measurement in the Hanks' solution at $37 \pm 1{ }^{\circ} \mathrm{C}$ from -1000 to $-300 \mathrm{mV}$ are shown in Figure 6.

Table 3. Electrochemical parameters of the Fe and Fe-PEI samples obtained from the Tafel analysis of polarization curves measured at $37 \pm 1^{\circ} \mathrm{C}$ in the Hanks' solution. Corrosion current $\left(\boldsymbol{i}_{\text {corr }}\right)$, corrosion current density $\left(j_{\text {corr }}\right)$, corrosion potential $\left(E_{\text {corr }}\right)$, polarization resistance $(P R)$, corrosion rate $(C R)$.

\begin{tabular}{cccccc}
\hline Sample & $\boldsymbol{E}_{\text {corr }}(\mathrm{V})$ & $\boldsymbol{i}_{\text {corr }}(\mathrm{A})$ & $j_{\text {corr }}\left(\boldsymbol{\mu} \mathrm{A} \mathrm{cm}^{-\mathbf{2}}\right)$ & $\boldsymbol{P R}\left(\boldsymbol{\Omega} \mathbf{c m}^{-2}\right)$ & $C R\left(\mathbf{m m ~ y}^{-\mathbf{1}}\right)$ \\
\hline Fe & -0.627 & $11.91 \times 10^{-5}$ & $1.18 \times 10^{-2}$ & 0.017 & 0.045 \\
Fe-PEI1 & -0.722 & $37.11 \times 10^{-5}$ & $4.52 \times 10^{-2}$ & 0.041 & 0.172 \\
Fe-PEI2 & -0.687 & $102.95 \times 10^{-5}$ & $3.10 \times 10^{-2}$ & 0.039 & 0.118 \\
Fe-PEI3 & -0.658 & $5.39 \times 10^{-5}$ & $15.49 \times 10^{-2}$ & 4.460 & 0.590 \\
\hline
\end{tabular}

The coating of the iron foams with the PEI has resulted in the shift of the corrosion potential to the more negative values obtained for all three different concentrations of polymer. The lowest value of $E_{c o r r}$ was observed for the Fe-PEI1, followed by the Fe-PEI2, Fe-PEI3, and the pure iron, which exhibited the most positive value $(-627.0 \mathrm{mV})$. Reported corrosion potentials of the pure iron observed by the anodic polarization method were $-860.7 \mathrm{mV}$ [41], $-484.0 \mathrm{mV}$ [50] or $-510.0 \mathrm{mV}$ [51]. For example, in [52], the authors studied electrochemical degradation of the pure iron bars and phosphated iron bars in Hanks' solution and observed the corrosion potential of pure iron to be $-670 \mathrm{mV}$, which is similar to that observed in this study. It can be seen, from the different results for the same composition of the sample (Fe), that the corrosion rate is dependent also on the preparation method and sample geometry. The foam-like structure of the samples prepared by the powder metallurgy method resulted in the shift of the electrochemical corrosion potential to more negative values when compared to that of standard pure iron. 


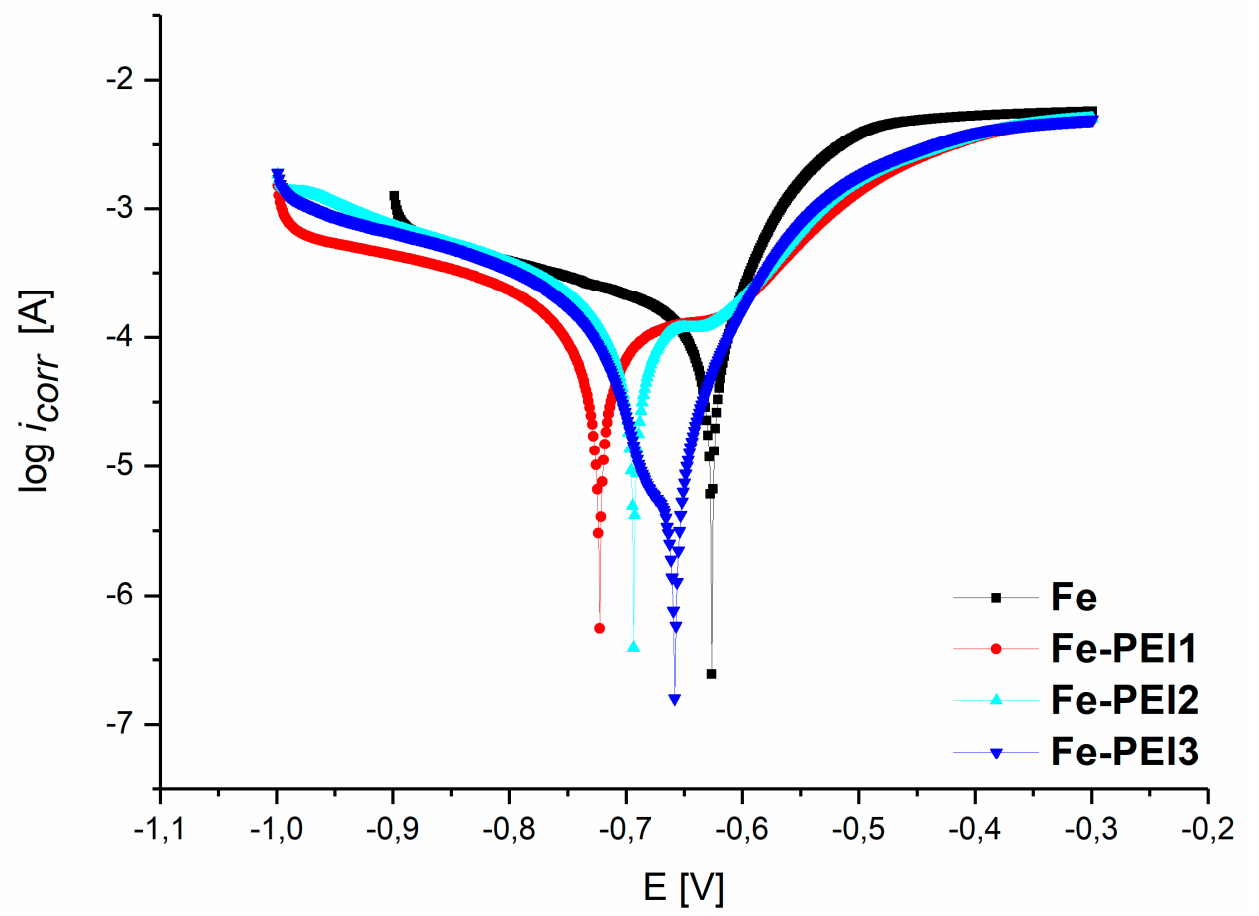

Figure 6. Polarization curves of the iron-based foams with or without PEI coating obtained in the Hanks' solution at $37 \pm 1{ }^{\circ} \mathrm{C}$.

The highest corrosion current density was observed for the Fe-PEI3 sample, indicating the highest ability to corrode. Corrosion rates (CR) calculated from Equation (1) confirmed that the highest corrosion rate from all the samples was the Fe-PEI3 sample, even though its polarization resistance $(P R)$ was the highest when compared to other samples. The determining parameter for such a behavior is the material surface area, as shown in Table 2. The specific surface area of the pure iron is, due to its inhomogeneity, almost 30 times higher when compared to the Fe-PEI3. This fact emphasizes the need to know the real surface areas during the evaluation of degradation behavior of polymer-coated samples with the tendency to lower $S_{B E T}$ values. Porous iron coated with PLGA [31] reached the corrosion rate of $0.420 \mathrm{~mm} \mathrm{y}^{-1}$, which is similar to the results of Fe-PEI3 material $\left(0.590 \mathrm{~mm} \mathrm{y}^{-1}\right)$. An important difference can be seen in the corrosion rates of pure iron, which is 5 times lower than that reported in [53]. This fact can be also attributed to the different surface areas of the pure iron sample affected by the preparation method and to the highly-porous structure. Similar values of $C R$ $(0.04 \pm 0.01)$ were observed in [16] for 3D-printed Fe-Mn samples, while in [51], the authors reported the $i_{\text {corr }}$ of pure Fe to be $1.68 \times 10^{-5} \mathrm{~A}$, which emphasizes even more the influence of the preparation method on the degradation behavior of biodegradable materials.

\subsubsection{Static Degradation Tests}

Static immersion tests provide complex information about the degradation processes of metallic samples and also about the changes in the corrosion medium. The most important advantage of this type of corrosion testing is its ability to simulate real-body conditions in a more authentic way than dynamic electrochemical tests. Pictures of iron and PEI-coated iron foams after degradation tests are shown in Figure 7. After 8 weeks of corrosion, all samples were completely covered with corrosion products in brown, red, and orange color forming the rust. With the prolonged time of immersion, surface roughness and inhomogeneity increased for all samples, as shown in Figures 8-10. Uniform corrosion, as shown in Figure 8a,b, was observed in the initial stage of degradation whereas pitting corrosion, as shown in Figure 9f,g, typical for the environment with high concentration of chloride ions [54], occurred with prolonged time of immersion. In Figure 10 are presented cross-sections of the 
Fe and Fe-PEI samples after 12 weeks of corrosion. The main difference, compared to the un-corroded material shown in Figure 4, could be observed in the thinning of the cell walls accompanied by cracking at the narrowest points, as shown in Figure 10c,d, which can lead to the worsening of the mechanical properties of such material.

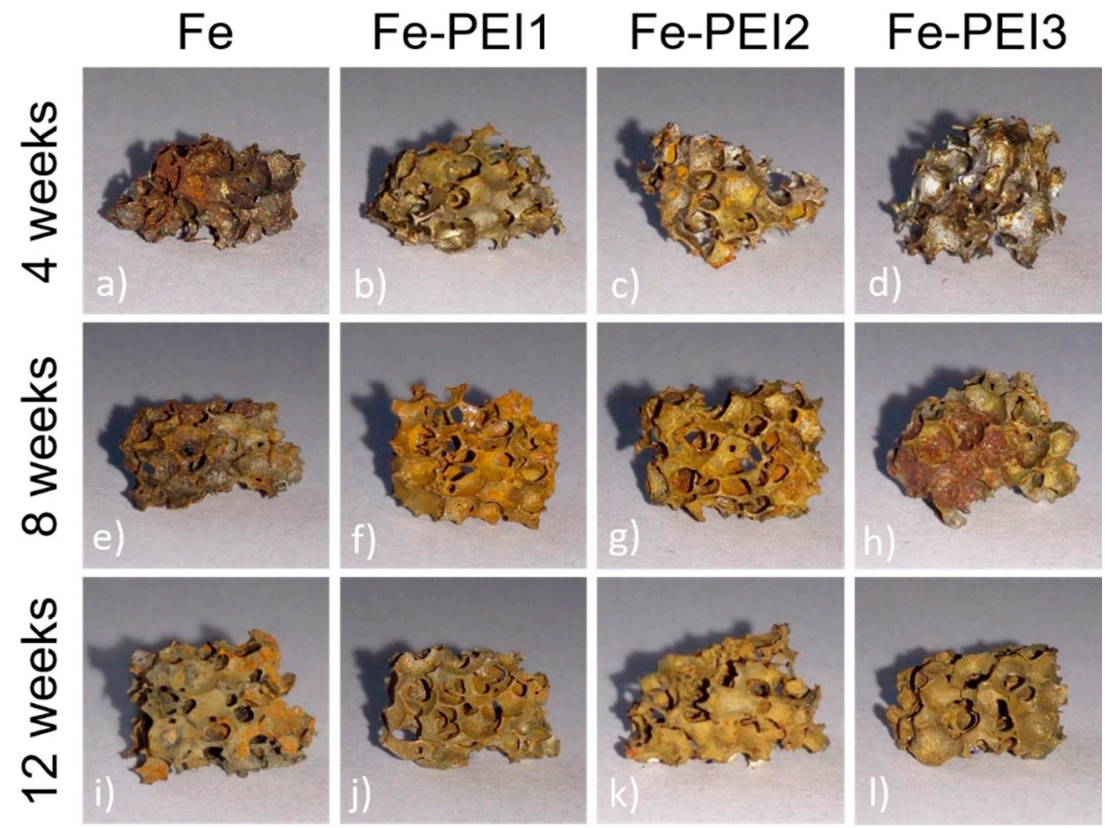

Figure 7. Cellular scaffold made of (a,e,i) pure Fe; (b,f,j) Fe-PEI1; (c,g,k) Fe-PEI2; and (d,h,l) Fe-PEI3 after a static immersion test in Hanks' solution at $37^{\circ} \mathrm{C}$.
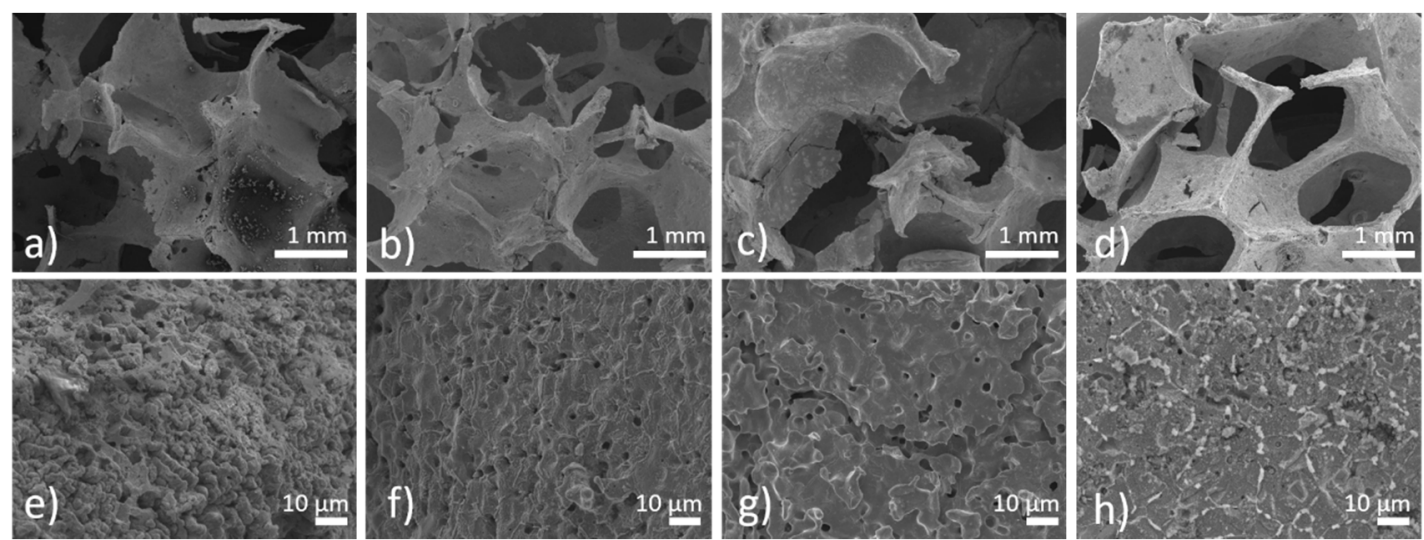

Figure 8. The SEM micrographs of the (a,e) Fe; (b,f) Fe-PEI1; (c,g) Fe-PEI2; and (d,h) Fe-PEI3 samples after 4 weeks of corrosion in the Hanks' solution at $37^{\circ} \mathrm{C}$.

Corrosion rates of the coated and uncoated iron-based foams were calculated from the weight loss values recorded after 4,8 , and 12 weeks. The slowest corrosion in the Hanks' solution at $37^{\circ} \mathrm{C}$ was observed for the pure iron, followed by the Fe-PEI1, Fe-PEI2, and Fe-PEI3, which is in accordance with the results obtained for Fe and Fe-PEI3 during the potentiodynamic tests. CR at different stages of the immersion experiment is listed in Table 4. Yusop et al. [31] have studied PLGA-coated iron and found the corrosion rate to be $0.76 \mathrm{~mm} \mathrm{y}^{-1}$, which is comparable to that of Fe-PEI3 determined in this study, as shown in Table 4. The degradation rate of pure iron did not change significantly during the testing period, whereas the CRs of Fe-PEI1 and Fe-PEI2 decreased with prolonged time. The Fe-PEI3 sample corroded fastest for the second month and its degradation slowed down during the third month due to the formation of a passivation layer of corrosion products. The thickest polymer layer 
deposited on the Fe-PEI3 sample could, therefore, serve as a corrosion barrier in the initial stage of the degradation process.
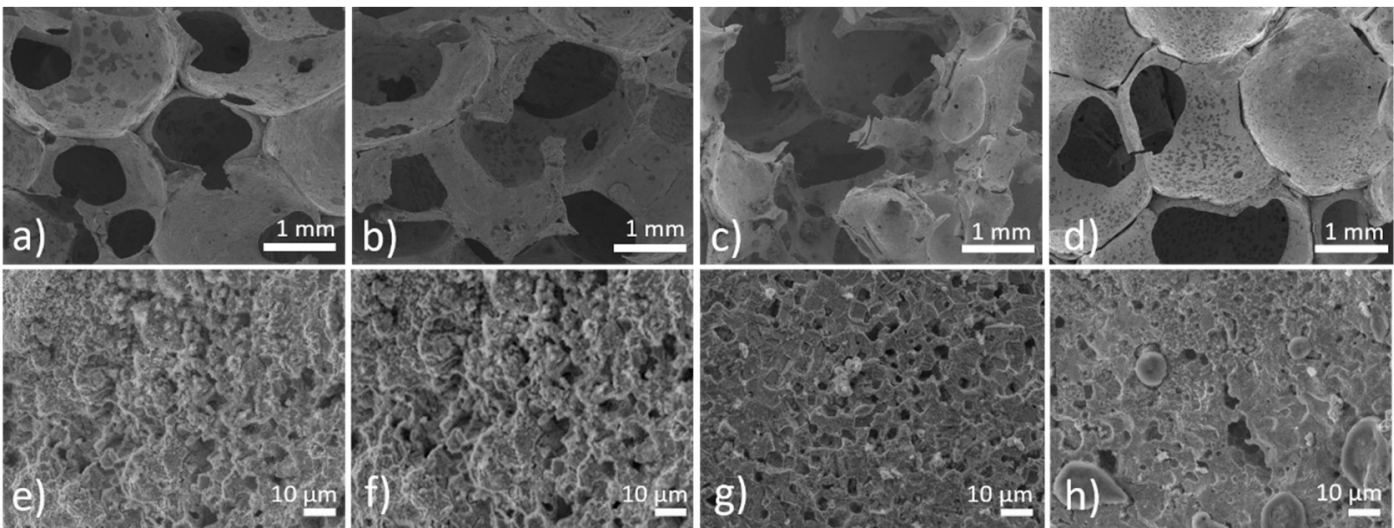

Figure 9. The SEM micrographs of the (a,e) Fe; $(\mathbf{b}, \mathbf{f})$ Fe-PEI1; (c, $\mathbf{g})$ Fe-PEI2; and (d,h) Fe-PEI3 samples after 12 weeks of corrosion in the Hanks' solution at $37^{\circ} \mathrm{C}$.
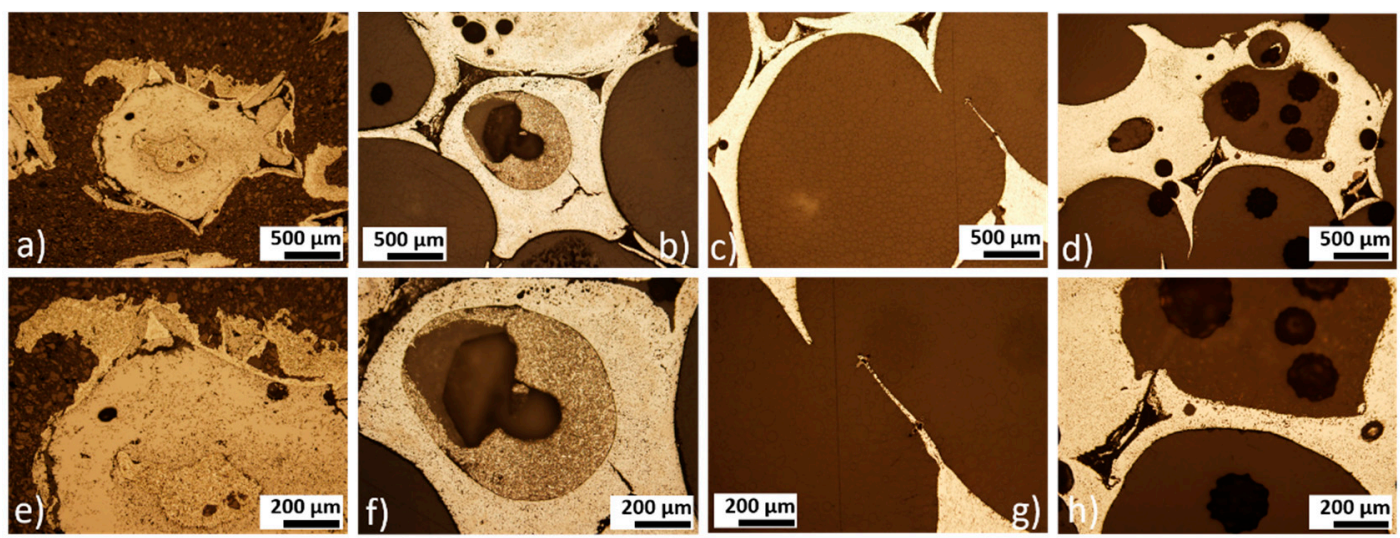

Figure 10. Metallographic cross-sections of the (a,e) pure iron; (b,f) Fe-PEI1; (c,g) Fe-PEI2; and (d,h) Fe-PEI3 after 12 weeks of corrosion.

Table 4. Corrosion rates of Fe, Fe-PEI1, Fe-PEI2, and Fe-PEI3 calculated from the weight-loss experiments in Hanks' solution at $37^{\circ} \mathrm{C}$ for 12 weeks.

\begin{tabular}{cccc}
\hline \multicolumn{4}{c}{$C \boldsymbol{R}\left[\mathrm{mm} \mathrm{y}^{-\mathbf{1}}\right]$} \\
\hline Week of Immersion & $\mathbf{4}$ & $\mathbf{8}$ & $\mathbf{1 2}$ \\
\hline Fe & $0.004 \pm 0.0015$ & $0.005 \pm 0.0030$ & $0.005 \pm 0.0034$ \\
Fe-PEI1 & $0.024 \pm 0.0052$ & $0.006 \pm 0.0008$ & $0.015 \pm 0.0047$ \\
Fe-PEI2 & $0.148 \pm 0.0420$ & $0.037 \pm 0.0113$ & $0.021 \pm 0.0209$ \\
Fe-PEI3 & $0.697 \pm 0.0398$ & $1.547 \pm 0.0793$ & $0.199 \pm 0.0109$ \\
\hline
\end{tabular}

The composition of the iron-based sample surface after 12 weeks of degradation is shown in Figure 11. All the samples were completely covered with the corrosion products comprising mostly of iron hydroxides. No evidence of nitrogen was observed, assuming total degradation of the PEI coating after three months, which was also confirmed by the FT-IR analysis, as shown in Figure 12. 

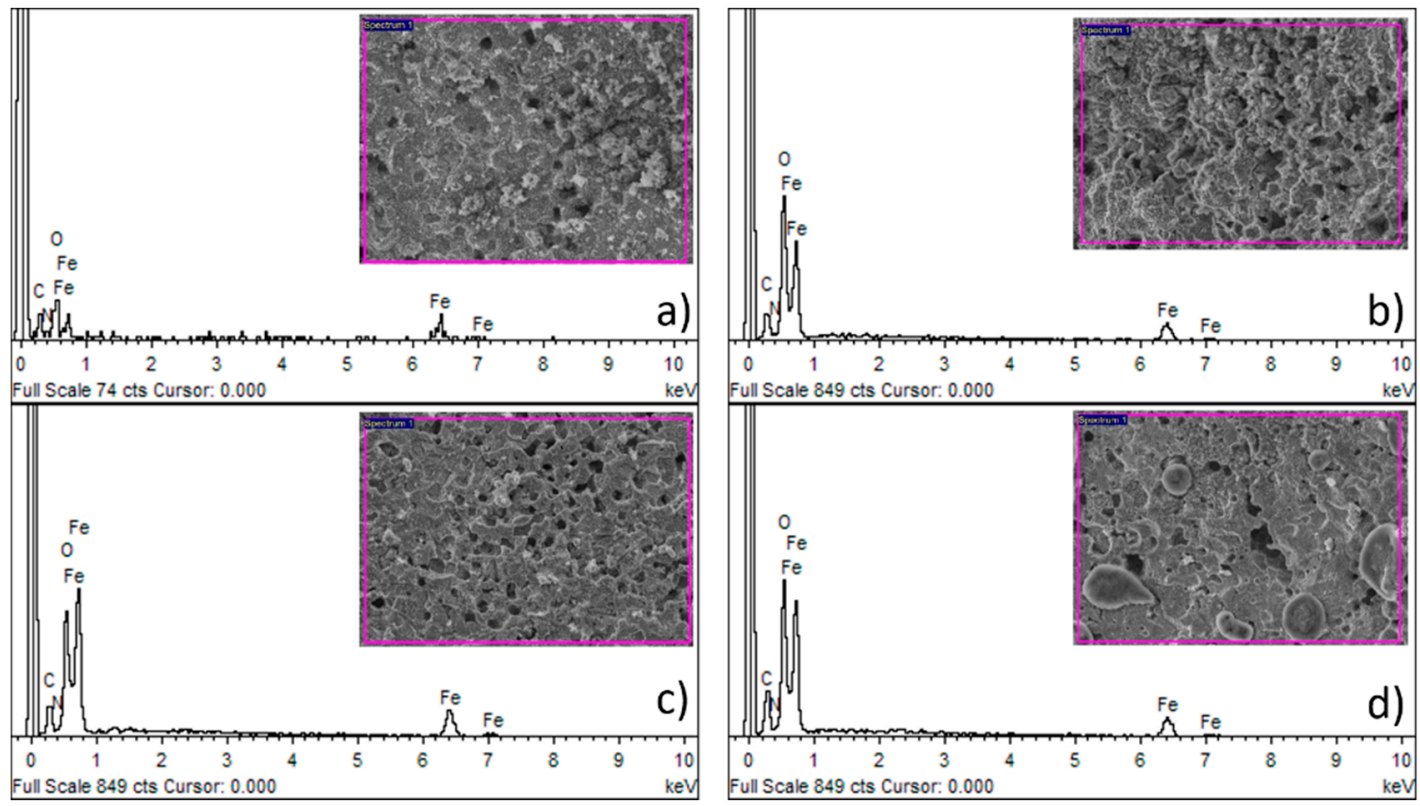

Figure 11. The chemical composition of the surface of (a) pure Fe; (b) Fe-PEI1; (c) Fe-PEI2; and (d) Fe-PEI3 after 12 weeks of corrosion in simulated body fluids studied by the EDX method.
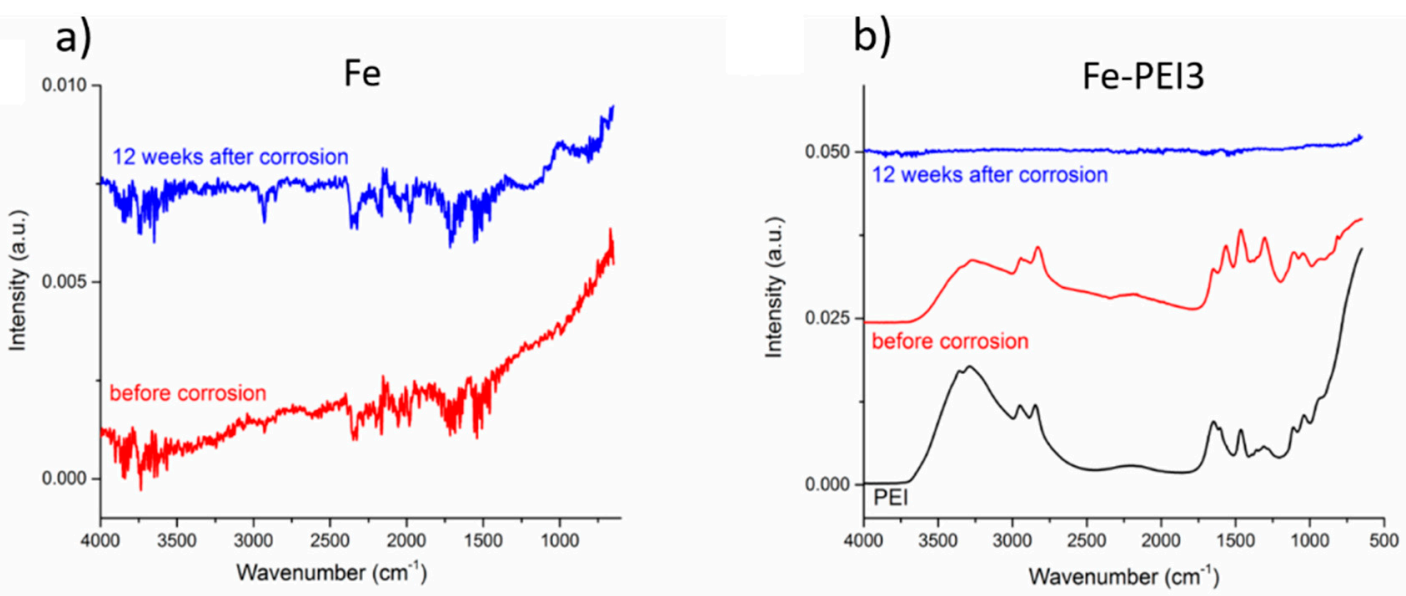

Figure 12. FT-IR spectra of (a) pure Fe; (b) Fe-PEI3 after 12 weeks of corrosion in Hanks' solution. Spectrum of pure PEI is added for better comparison.

The influence of the corrosion environment on the Fe and Fe-PEI was investigated by FT-IR, as shown in Figure 13a,b, respectively. In Figure 13b, the spectrum of PEI is also included for comparison. The individual intensities of the spectra were adjusted in order to create a comparable figure, namely, the intensities of the polymer and Fe-PEI samples were decreased 10 and 5 times, respectively. The spectra of iron, as shown in Figure 13a, before and after corrosion are almost identical; the differences stay within the measurement error. Neither of the samples exhibit a significant band in FT-IR. The difference between the spectrum of the pure PEI and Fe-PEI specimen was already described earlier. After 12 weeks of corrosion, no bands can be observed, thus the organic layer was completely decomposed. Reactions ongoing during iron degradation in Hanks' solution were already described [23]. 

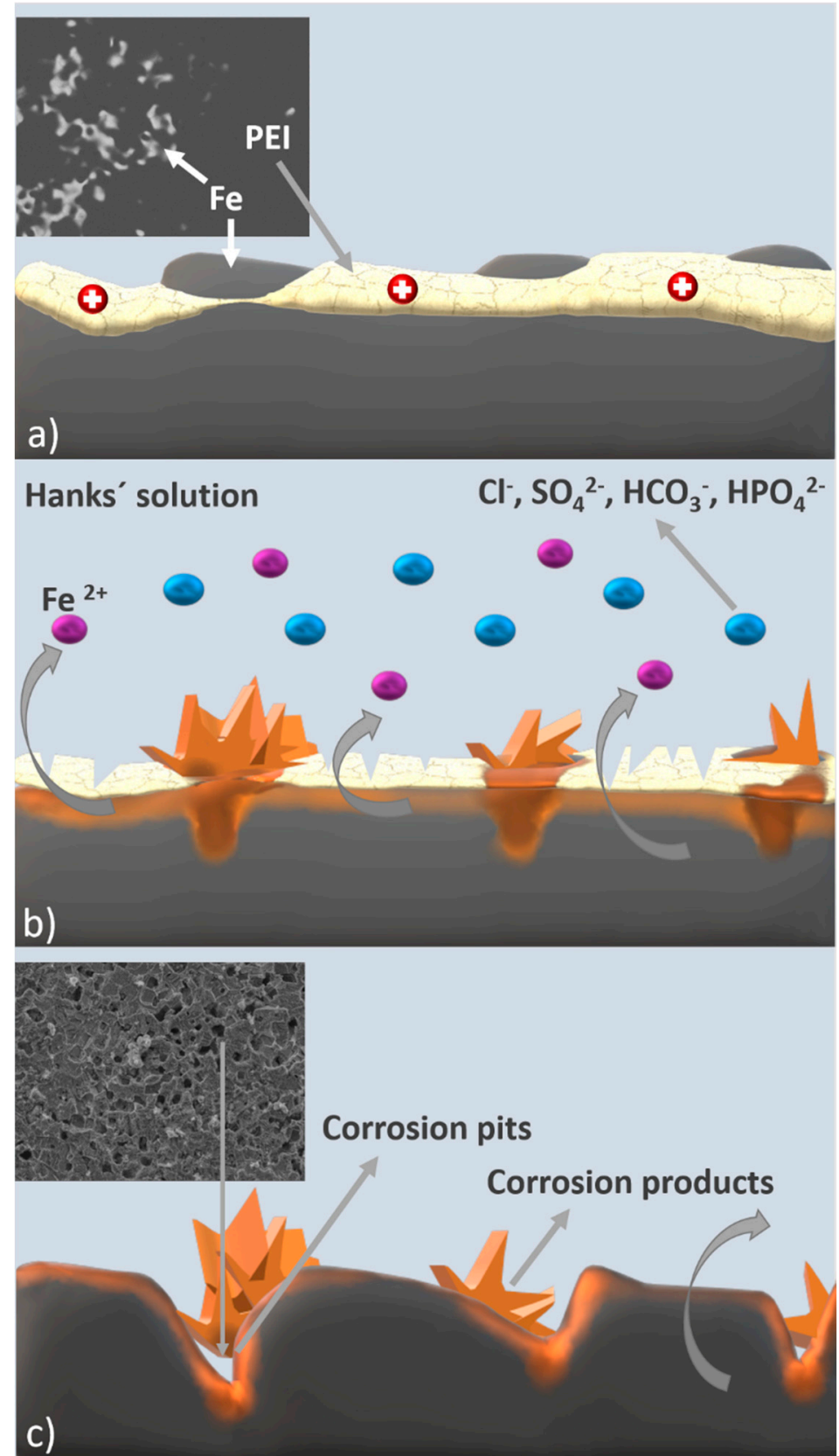

Figure 13. Schematic representation of corrosion processes ongoing on the surface of the Fe-PEI material. (a) Polymer-coated sample on-air; (b) polymer-coated sample after immersion into Hanks' solution-PEI layer disruption; (c) formation of corrosion pits after 12 weeks of biodegradation.

Yusop et al. [31] have suggested accelerated corrosion as a consequence of lowering of $\mathrm{pH}$ induced by the polymer hydrolysis. The $\mathrm{pH}$ of the Hanks' solution was measured during the immersion study and results are listed in Table 5. After 4 weeks, $\mathrm{pH}$ of the corrosion medium was slightly shifted to the higher values. In the case of pure iron and the Fe-PEI3 sample, the constant rise of $\mathrm{pH}$ was observed with resultant values of 8.06 and 8.73 , respectively. $\mathrm{pH}$ values of all of the tested samples were higher at the end of the immersion study and exceeded the value of $\mathrm{pH}=8$. More basic $\mathrm{pH}$ can be attributed to the creation of the corrosion products (e.g., $\left.\mathrm{Fe}(\mathrm{OH})_{2}, \mathrm{Fe}(\mathrm{OH})_{3}, \mathrm{FeCl}_{2} \mathrm{OH}\right)$. Fe-PEI1 and Fe-PEI2 degradation resulted in the lowering of the $\mathrm{pH}$ after 8 weeks of the immersion. It is possible that in the case of higher PEI concentration (PEI3), the degradation of the polymeric layer is more rapid in the initial stage (before the fourth week). It increases solubility of the layer of corrosion products, which 
results in enhanced corrosion, and therefore in the higher content of corrosion products in the Hanks' solution responsible for basic $\mathrm{pH}$. As long as PEI can act as a buffering agent, residual acidity created at the beginning of the degradation process can be compensated by the protonation of PEI functional amino groups.

Table 5. pH of Hanks' solution after 4 to 12 weeks long immersion of iron-based samples coated with PEI and pure iron foams.

\begin{tabular}{ccccc}
\hline \multicolumn{5}{c}{$\mathbf{p H} \mathbf{0 . 2}$} \\
Week of Immersion & $\mathbf{0}$ & $\mathbf{4}$ & $\mathbf{8}$ & $\mathbf{1 2}$ \\
\hline Fe & 7.40 & 7.46 & 7.75 & 8.06 \\
Fe-PEI1 & 7.40 & 7.43 & 7.06 & 8.08 \\
Fe-PEI2 & 7.40 & 7.69 & 7.53 & 8.23 \\
Fe-PEI3 & 7.40 & 7.48 & 8.25 & 8.73 \\
\hline
\end{tabular}

Degradation of the polymer caused creation of the localized cracks and pits which served as an entrance for corrosive medium into the depth of the sample, as shown in Figure 13. This can explain the corrosion rate enhancement of coated samples and presence of the pitting corrosion. Moreover, chelation processes between polymer and metal ions [55] could contribute to the higher content of the iron in the solution. Atomic absorption spectroscopy was used to determine the total concentration of the iron ( $\left.\mathrm{mg} \mathrm{mL}^{-1}\right)$ in the medium, as shown in Table 6. All the observed values increased with prolonged time of immersion, with the highest amount of $0.0337 \mathrm{mg} \mathrm{mL}^{-1}$ for Fe-PEI3. Information about the iron concentration released into solution is important for further determination of material cytotoxicity.

Table 6. Total iron concentration observed in the Hanks' solution after 4, 8, and 12 weeks of immersion of cellular scaffolds with polymer (PEI) coating.

\begin{tabular}{cccc}
\hline \multicolumn{4}{c}{ Total Iron Concentration $\left(\mathbf{m g ~ m L}^{-\mathbf{1}}\right)$} \\
\hline Week of Immersion & $\mathbf{4}$ & $\mathbf{8}$ & $\mathbf{1 2}$ \\
\hline Fe & 0.0243 & 0.0265 & 0.0316 \\
Fe-PEI1 & 0.0151 & 0.0278 & 0.0284 \\
Fe-PEI2 & 0.0184 & 0.0224 & 0.0251 \\
Fe-PEI3 & 0.0139 & 0.0283 & 0.0337 \\
\hline
\end{tabular}

Zhang [51] reported that iron concentration lower than $0.075 \mathrm{mg} \mathrm{mL}^{-1}$ is safe for cells, therefore it can be assumed that biodegradable foams studied in this paper should not possess cytotoxicity based on the amount of released metal ions into the body. Cytotoxicity and hemocompatibility studies of the material are therefore necessary for its further evaluation.

\section{Conclusions}

Iron-based foams with open-cell porosity were prepared and analyzed. The deposition of the polymeric (PEI) layer on the surface of the samples led to the changes in their morphology. A significant decrease in the surface area was observed after the application of coating (from $1.19 \mathrm{mg} \mathrm{m}^{-2}$ for pure iron to $0.04 \mathrm{mg} \mathrm{m}^{-2}$ for Fe-PEI3). Moreover, desirable corrosion rate enhancement mediated through the polymer cracking and corrosion medium penetration enabling took place in the case of polymer-coated samples.

Based on the results reported in this study, coating with polymers can lead to changes in the corrosion rates of metallic samples. Variations in their concentrations seem to be an appropriate way to design devices with desired degradation behavior. PEI is a flexible polymer that can be further functionalized, which makes a room for its future modification. Loading PEI with drugs that could help in bone treatment processes should be an interesting challenge for future research. 
Author Contributions: Conceptualization, R.O. and A.O.; Investigation, R.G., Z.O.K., M.B., M.K., M.H., L.H., M.D., F.K., and K.K.; Supervision, R.O.; Writing-original draft, R.G.; Writing-review \& editing, R.O. All authors have read and agreed to the published version of the manuscript.

Funding: This research received no external funding.

Acknowledgments: This work was supported by the projects APVV-16-0029 and APVV-18-0357 of the Slovak Research and Development Agency, VEGA 1/0074/17 and VEGA 2/0044/18 of the Slovak Scientific Grant Agency, and VVGS-PF-2019-1049 of the Internal Research Grant System of Faculty of Science of P. J. Šafárik University. The authors would like to thank Zuzana Jurašeková, from the Department of Biophysics and Center for Interdisciplinary Biosciences, Faculty of Science, P.J. Šafárik University, for facilitating the measurement of the Raman spectra.

Conflicts of Interest: The authors declare no conflict of interest.

\section{References}

1. Wu, G.; Ibrahim, J.M. Surface design of biodegradable magnesium alloys-A review. Surf. Coat. Technol. 2013, 233, 2-12. [CrossRef]

2. Yun, Y.; Dong, Z.; Lee, N.; Liu, Y.; Xue, D.; Guo, X.; Kuhlmann, J.; Doepke, A.; Halsall, H.B.; Heineman, W.; et al. Revolutionizing biodegradable metals. Mater. Today 2009, 12, 22-32. [CrossRef]

3. Han, H.S.; Loffredo, S.; Jun, I.; Edwards, J.; Kim, Y.C.; Seok, H.K.; Witte, F.; Mantovani, D.; Glyn-Jones, S. Current status and outlook on the clinical translation of biodegradable metals. Mater. Today 2019, 23, 57-71. [CrossRef]

4. Li, H.; Zheng, Y.; Qin, L. Progress of biodegradable metals. Prog. Nat. Sci. Mater. Int. 2014, $24,414-422$. [CrossRef]

5. Tan, L.; Yu, X.; Wan, P.; Yang, K. Biodegradable materials for bone repairs: a review. J. Mater. Sci. Technol. 2013, 6, 503-513. [CrossRef]

6. Yusop, A.H.; Bakir, A.A.; Shaharom, N.A.; Abdul Kadir, M.R.; Hermawan, H. Porous Biodegradable Metals for Hard Tissue Scaffolds: A Review. Int. J. Biomater. 2012, 2012. [CrossRef] [PubMed]

7. Seitz, J.M.; Durisin, M.; Goldman, J.; Drelich, J.W. Recent Advances in Biodegradable Metals for Medical Sutures: A Critical Review. Adv. Healthc. Mater. 2015, 4, 1915-1936. [CrossRef]

8. Mahyudin, F.; Widhiyanto, L.; Hermawan, H. Biomaterials in orthopaedics. In Biomaterials and Medical Devices; Springer: Cham, Switzerland, 2016; pp. 161-181.

9. Kraus, T.; Moszner, F.; Fischerauer, S.; Fiedler, M.; Martinelli, E.; Eichler, J.; Witte, F.; Willbold, E.; Schinhammer, M.; Meischel, M.; et al. Biodegradable Fe-based alloys for use in osteosynthesis: Outcome of an in vivo study after 52 weeks. Acta Biomater. 2014, 10, 3346-3353. [CrossRef]

10. Schinhammer, M.; Steiger, P.; Moszner, F.; Löffler, J.F.; Uggowitzer, P.J. Degradation performance of biodegradable FeMnC(Pd) alloys. Mater. Sci. Eng. C 2013, 33, 1882-1893. [CrossRef]

11. Huang, T.; Cheng, J.; Zheng, Y.F. In vitro degradation and biocompatibility of Fe-Pd and Fe-Pt composites fabricated by spark plasma sintering. Mater. Sci. Eng. C 2014, 35, 43-53. [CrossRef]

12. Schinhammer, M.; Hänzi, A.C.; Löffler, J.F.; Uggowitzer, P.J. Design strategy for biodegradable Fe-based alloys for medical applications. Acta Biomater. 2010, 6, 1705-1713. [CrossRef] [PubMed]

13. Chou, D.T.; Wells, D.; Hong, D.; Lee, B.; Kuhn, H.; Kumta, P.N. Novel processing of iron-manganese alloy-based biomaterials by inkjet 3-D printing. Acta Biomater. 2013, 9, 8593-8603. [CrossRef] [PubMed]

14. Oriňaková, R.; Oriňak, A.; Markušová, L.; Labbanczová, E.; Kupková, M.; Hrubovčáková, M.; Fedorková, A. Biodegradable Open Cell Iron Foams for Potential Skeletal Application. Powder Metall. Prog. 2012, 12, 219-223.

15. Hermawan, H.; Alamdari, H.; Mantovani, D.; Dubé, D. Iron-manganese: New class of metallic degradable biomaterials prepared by powder metallurgy. Powder Metall. 2008, 51, 38-45. [CrossRef]

16. Hong, D.; Chou, D.T.; Velikokhatnyi, O.I.; Roy, A.; Lee, B.; Swink, I.; Issaev, I.; Kuhn, H.A.; Kumta, P.N. Binder-jetting 3D printing and alloy development of new biodegradable Fe-Mn-Ca/Mg alloys. Acta Biomater. 2016, 45, 375-386. [CrossRef]

17. Cheng, J.; Huang, T.; Zheng, Y.F. Microstructure, mechanical property, biodegradation behavior, and biocompatibility of biodegradable Fe-Fe2O3 composites. J. Biomed. Mater. Res. Part A 2014, 102, 2277-2287. [CrossRef] 
18. Bakhsheshi-Rad, H.R.; Ismail, A.F.; Aziz, M.; Hadisi, Z.; Omidi, M.; Chen, X. Antibacterial activity and corrosion resistance of $\mathrm{Ta}_{2} \mathrm{O}_{5}$ thin film and electrospun PCL/MgO-Ag nanofiber coatings on biodegradable Mg alloy implants. Ceram. Int. 2019, 45, 11883-11892. [CrossRef]

19. Bakhsheshi-Rad, H.R.; Akbari, M.; Ismail, A.F.; Aziz, M.; Hadisi, Z.; Pagan, E.; Daroonparvar, M.; Chen, X. Coating biodegradable magnesium alloys with electrospun poly-L-lactic acid-åkermanite-doxycycline nanofibers for enhanced biocompatibility, antibacterial activity, and corrosion resistance. Surf. Coat. Technol. 2019, 377, 124898. [CrossRef]

20. Hufenbach, J.; Wendrock, H.; Kochta, F.; Kühn, U.; Gebert, A. Novel biodegradable Fe-Mn-C-S alloy with superior mechanical and corrosion properties. Mater. Lett. 2017, 186, 330-333. [CrossRef]

21. Cheng, J.; Zheng, Y.F. In vitro study on newly designed biodegradable Fe-X composites $(X=W, C N T)$ prepared by spark plasma sintering. J. Biomed. Mater. Res. Part B Appl. Biomater. 2013, 4, 485-497. [CrossRef]

22. Zhang, Q.; Cao, P. Degradable porous Fe-35wt.\%Mn produced via powder sintering from $\mathrm{NH}_{4} \mathrm{HCO}_{3}$ porogen. Mater. Chem. Phys. 2015, 163, 394-401. [CrossRef]

23. Gorejová, R.; Haverová, L.; Oriňaková, R.; Oriňak, A.; Oriňak, M. Recent advancements in Fe-based biodegradable materials for bone repair. J. Mater. Sci. 2019, 54, 1913-1947. [CrossRef]

24. Čapek, J.; Vojtěch, D.; Oborná, A. Microstructural and mechanical properties of biodegradable iron foam prepared by powder metallurgy. Mater. Des. 2015, 83, 468-482. [CrossRef]

25. Li, Y.; Jahr, H.; Lietaert, K.; Pavanram, P.; Yilmaz, A.; Fockaert, L.; Leeflang, M.A.; Pouran, B.; Gonzalez-Garcia, Y.; Weinans, H.; et al. Additively manufactured biodegradable porous iron. Acta Biomater. 2018, 77, 380-393. [CrossRef]

26. Posada, V.M.; Orozco, C.; Ramirez Patino, J.F.; Fernandez-Morales, P. Human Bone Inspired Design of an Mg Alloy-Based Foam. Mater. Sci. Forum 2018, 933, 291-296. [CrossRef]

27. Daud, N.M.; Sing, N.B.; Yusop, A.H.; Majid, F.A.A.; Hermawan, H. Degradation and in vitro cell-material interaction studies on hydroxyapatite-coated biodegradable porous iron for hard tissue scaffolds. J. Orthop. Transl. 2014, 2, 177-184.

28. Oriňaková, R.; Oriňak, A.; Kupková, M.; Hrubovčáková, M.; Markušová-Bučková, L.; Giretová, M.; Medvecký, L.; Dobročka, E.; Petruš, O.; Kal'avský, F. In vitro degradation and cytotoxicity evaluation of iron biomaterials with hydroxyapatite film. Int. J. Electrochem. Sci. 2015, 10, 8158-8174.

29. Wang, S.; Xu, Y.; Zhou, J.; Li, H.; Chang, J.; Huan, Z. In vitro degradation and surface bioactivity of iron-matrix composites containing silicate-based bioceramic. Bioact. Mater. 2017, 2, 10-18. [CrossRef]

30. Haverová, L.; Oriňaková, R.; Oriňak, A.; Gorejova, R.; Baláž, M.; Vanýsek, P.; Kupkova, M.; Hrubovčáková, M.; Mudroň, P.; Radoňák, J.; et al. An In Vitro Corrosion Study of Open Cell Iron Structures with PEG Coating for Bone Replacement Applications. Metals 2018, 8, 499. [CrossRef]

31. Yusop, A.H.M.; Daud, N.M.; Nur, H.; Kadir, M.R.A.; Hermawan, H. Controlling the degradation kinetics of porous iron by poly(lactic-co-glycolic acid) infiltration for use as temporary medical implants. Sci. Rep. 2015, 5, 11194. [CrossRef]

32. Oriňaková, R.; Gorejová, R.; Macko, J.; Oriňak, A.; Kupková, M.; Hrubovčáková, M.; Ševc, J.; Smith, R.M. Evaluation of in vitro biocompatibility of open cell iron structures with PEG coating. Appl. Surf. Sci. 2019, 475, 515-518. [CrossRef]

33. Vancha, A.R.; Govindaraju, S.; Parsa, K.V.L.; Jasti, M.; González-García, M.; Ballestero, R.P. Use of polyethyleneimine polymer in cell culture as attachment factor and lipofection enhancer. BMC Biotechnol. 2004, 4, 1-12. [CrossRef] [PubMed]

34. Yang, F.; Hu, S.; Lu, Y.; Yang, H.; Zhao, Y.; Li, L. Effects of coatings of polyethyleneimine and thyme essential oil combined with chitosan on sliced fresh channa argus during refrigerated storage. J. Food Process Eng. 2015, 38, 225-233. [CrossRef]

35. Xia, T.; Kovochich, M.; Liong, M.; Meng, H.; Kabehie, S.; George, S.; Zink, J.I.; Nel, A.E. Polyethyleneimine coating enhances the cellular uptake of mesoporous silica nanoparticles and allows safe delivery of siRNA and DNA constructs. ACS Nano 2009, 3, 3273-3286. [CrossRef] [PubMed]

36. Islam, M.A.; Park, T.E.; Singh, B.; Maharjan, S.; Firdous, J.; Cho, M.H.; Kang, S.K.; Yun, C.H.; Choi, Y.J.; Cho, C.S. Major degradable polycations as carriers for DNA and siRNA. J. Control. Release 2014, 193, 74-89. [CrossRef] [PubMed] 
37. Li, J.; Zheng, L.; Cai, H.; Sun, W.; Shen, M.; Zhang, G.; Shi, X. Polyethyleneimine-mediated synthesis of folic acid-targeted iron oxide nanoparticles for invivo tumor MR imaging. Biomaterials 2013, 34, 8382-8392. [CrossRef]

38. Yao, X.; Zhou, N.; Wan, L.; Su, X.; Sun, Z.; Mizuguchi, H.; Yoshioka, Y.; Nakagawa, S.; Zhao, R.C.; Gao, J.Q. Polyethyleneimine-coating enhances adenoviral transduction of mesenchymal stem cells. Biochem. Biophys. Res. Commun. 2014, 447, 383-387. [CrossRef]

39. Dong, P.; Hao, W.; Wang, X.; Wang, T. Fabrication and biocompatibility of polyethyleneimine/heparin self-assembly coating on NiTi alloy. Thin Solid Films 2008, 516, 5168-5171. [CrossRef]

40. Bergstrand, A.; Rahmani-Monfared, G.; Östlund, Å.; Nydén, M.; Holmberg, K. Comparison of PEI-PEG and PLL-PEG copolymer coatings on the prevention of protein fouling. J. Biomed. Mater. Res. Part A 2009, 88, 608-615. [CrossRef]

41. Oriňaková, R.; Oriňak, A.; Bučková, L.M.; Giretová, M.; Medvecký, L.; Labbanczová, E.; Kupková, M.; Hrubovčáková, M.; Koval', K. Iron based degradable foam structures for potential orthopedic applications. Int. J. Electrochem. Sci. 2013, 8, 12451-12465.

42. Yin, C.Y.; Aroua, M.K.; Daud, W.M.A.W. Metal-polyethyleneimine-activated carbon interaction parameter at equilibrium adsorption capacity. J. Appl. Sci. 2010, 10, 1192-1195. [CrossRef]

43. Dhiman, M.; Chalke, B.; Polshettiwar, V. Efficient Synthesis of Monodisperse Metal (Rh, Ru, Pd) Nanoparticles Supported on Fibrous Nanosilica (KCC-1) for Catalysis. ACS Sustain. Chem. Eng. 2015, 3, 3224-3230. [CrossRef]

44. Li, J.; Tang, W.; Yang, H.; Dong, Z.; Huang, J.; Li, S.; Wang, J.; Jin, J.; Ma, J. Enhanced-electrocatalytic activity of Ni 1-x Fe $x$ alloy supported on polyethyleneimine functionalized MoS 2 nanosheets for hydrazine oxidation. RSC Adv. 2014, 4, 1988-1995. [CrossRef]

45. Singh, S.; Thomas, V.; Martyshkin, D.; Kozlovskaya, V.; Kharlampieva, E.; Catledge, S.A. Spatially controlled fabrication of a bright fluorescent nanodiamond-array with enhanced far-red Si-V luminescence. Nanotechnology 2014, 25, 045302. [CrossRef] [PubMed]

46. Liu, Y.; Liu, J.; Yao, W.; Cen, W.; Wang, H.; Weng, X.; Wu, Z. The effects of surface acidity on $\mathrm{CO}_{2}$ adsorption over amine functionalized protonated titanate nanotubes. RSC Adv. 2013, 3, 18803-18810. [CrossRef]

47. Sanchez-Cortes, S.; Berenguel, R.M.; Madejón, A.; Pérez-Méndez, M. Adsorption of polyethyleneimine on silver nanoparticles and its interaction with a plasmid DNA: A surface-enhanced Raman scattering study. Biomacromolecules 2002, 3, 655-660. [CrossRef] [PubMed]

48. Rezaei, F.; Jones, C.W. Stability of Supported Amine Adsorbents to $\mathrm{SO}_{2}$ and $\mathrm{NOx}$ in Postcombustion $\mathrm{CO}_{2}$ Capture. 1. Single-Component Adsorption. Ind. Eng. Chem. Res. 2013, 52, 12192-12201. [CrossRef]

49. Chaufer, B.; Rabiller-Baudry, M.; Bouguen, A.; Labbé, J.P.; Quémerais, A. Spectroscopic characterization of zirconia coated by polymers with amine groups. Langmuir 2000, 16, 1852-1860. [CrossRef]

50. Kupková, M.; Hrubovčáková, M.; Kupka, M.; Oriňáková, R.; Turoňová, A.M. Corrosion behaviour of powder metallurgy biomaterials from phosphated carbonyl-iron powders. Int. J. Electrochem. Sci. 2015, 10, 671-681.

51. Zhang, E.; Chen, H.; Shen, F. Biocorrosion properties and blood and cell compatibility of pure iron as a biodegradable biomaterial. J. Mater. Sci. Mater. Med. 2010, 21, 2151-2163. [CrossRef]

52. Chen, H.; Zhang, E.; Yang, K. Microstructure, corrosion properties and bio-compatibility of calcium zinc phosphate coating on pure iron for biomedical application. Mater. Sci. Eng. C 2014, 34, 201-206. [CrossRef] [PubMed]

53. Kupková, M.; Hrubovčáková, M.; Kupka, M.; Oriňaková, R.; Turoňová, A.M. Sintering behaviour, graded microstructure and corrosion performance of sintered Fe-Mn biomaterials. Int. J. Electrochem. Sci. 2015, 10, 9256-9268.

54. Wei, J.; Zhou, B.; Wan, T.; Liu, K.; Gong, S.; Wu, J.; Xu, S. Effect of Sulfate and Chloride ions on pitting corrosion behavior of $2 \mathrm{Cr} 12 \mathrm{MoV}$ Steel at $\mathrm{pH} 6$ and $90^{\circ} \mathrm{C}$. Int. J. Electrochem. Sci. 2018, 13, 11596-11606. [CrossRef]

55. Kislenko, V.N.; Oliynyk, L.P. Complex formation of polyethyleneimine with copper(II), nickel(II), and cobalt(II) ions. J. Polym. Sci. Part A Polym. Chem. 2002, 40, 914-922. [CrossRef]

(C) 2020 by the authors. Licensee MDPI, Basel, Switzerland. This article is an open access article distributed under the terms and conditions of the Creative Commons Attribution (CC BY) license (http://creativecommons.org/licenses/by/4.0/). 